\section{Cell Derived Microparticles in Gingival Crevicular Fluid from Periodontitis Patients with Type 2 Diabetes}

\author{
Carlos Marcelo Figueredo, Ronaldo Lira-Junior, Manuela Rubim Sete, Ricardo \\ Guimarães Fischer
}

Department of Periodontology, School of Dentistry, UERJ Universidade do Estado do Rio de Janeiro, Rio de Janeiro, RJ, Brazil

Correspondence: Carlos Marcelo Figueredo, Boulevard 28 de Setembro 157, $2^{\circ}$ Andar, Vila lsabel, 20551030 Rio de Janeiro, RJ, Brasil. Tel: +55-21-2868-8282. e-mail: cmfigueredo@hotmail.com

\begin{abstract}
Cell-derived microparticles (MPs) have been described as vital contributors to the inflammatory process. However, its role in the periodontal disease pathogenesis remains unclear. Therefore, we aimed to detect the presence neutrophil (CD66b+) and platelet $(C D 41 b+)$ derived microparticles in gingival crevicular fluid from individuals having periodontitis aggravated by type 2 diabetes. Twelve patients ( $56.2 \pm 7.2 \mathrm{yrs}$ ) with severe form of chronic periodontitis aggravated by type 2 diabetes were included. Clinical and metabolic data were gathered. Gingival crevicular fluid was collected using filter strips from deep and shallow sites. MPs were detected by flow cytometry according to their size $(<1 \mu \mathrm{m})$ and the expression of surface markers (CD66b for neutrophil-derived MPs and CD41b for platelet-derived MPs). All samples were positive for the antibodies. Median levels of CD66b+ MPs and CD41b+ MPs were, respectively, 3,677.0 (2,553.2 - 9,059.8) $\mathrm{MP} / \mu \mathrm{L}$ and $520.7(432.9-766.1) \mathrm{MP} / \mu \mathrm{L}$ in deep sites. In shallow sites, the corresponding values were 2,644.9 $(1,451.5-3,858.9) \mathrm{MP} / \mu \mathrm{L}$ and $371.2(287.2-692.7) \mathrm{MP} / \mu \mathrm{L}$. There was no significant difference between deep and shallow sites $(p>0.05)$. In conclusion, this study reported the presence of neutrophil and platelet derived microparticles in gingival crevicular fluid from individuals having severe periodontitis and type 2 diabetes.
\end{abstract}

Key Words: chronic periodontitis, diabetes, gingival crevicular fluid, cell-derived microparticles.

\section{Introduction}

Cell-derived microparticles (MPs) are extracellular vesicles derived from plasma membrane budding as phospholipid vesicles known to express antigens specific of their parental cells(1). MPs are released after stimulation or apoptosis and their composition vary according to the stimulus and cells they originated from. MPs are important players for the intercellular exchange of biological information and they can carry cytokines, enzymes, autoantigens, mRNA, and microRNA (1).

MPs can induce, amplify and/or modulate the immune response, as well as to endue recipient cells with new functional properties, such as the migratory ability. Given their essential function in several physiological processes, MPs have been shown to play an important role in inflammatory and metabolic diseases. Plasma levels of MPs are altered in rheumatoid arthritis (2), oral cancer (3) and diabetes (4). Although the presence of MPs in saliva, urine, bronchoalveolar lavage and synovial fluid have already been shown $(5,6)$, its detection in gingival crevicular fluid (GCF) still needs to be confirmed.

The detection of MPs in GCF might be potentialized in patients having type 2 diabetes, since MPs are increased in circulation and also seem to be involved in the development of diabetic complications (7). Therefore, we aimed to detect the presence neutrophil and platelet derived microparticles in gingival crevicular fluid from periodontitis patients with type 2 diabetes.

\section{Matrial and Methods Patients}

Our study enrolled 12 patients with severe periodontitis and type 2 diabetes. Patients were selected from the outpatient dental clinic at the Rio de Janeiro State University. Severe periodontitis was defined as the presence of at least two interproximal sites with clinical attachment loss (CAL) $\geq 6 \mathrm{~mm}$, not on the same tooth and at least one site with probing depth $(P D) \geq 5 \mathrm{~mm}$, excluding third molars (8). Diabetes was reported by the patient based on physician's diagnosis and the use of medication. The study was approved by the Ethics Committee in Research of Pedro Ernesto University Hospital of the Rio de Janeiro State University. All patients gave their written informed consent.

Data regarding demographic and metabolic variables were gathered. A comprehensive periodontal examination was performed by a calibrated examiner using a manual probe (UNC-15; Hu-Friedy Manufacturing Company, USA). Full-mouth CAL, PD, plaque index (PI) and bleeding on probing $(\mathrm{BOP})$ were registered. $\mathrm{CAL}$ and $\mathrm{PD}$ were assessed in six sites per tooth and $\mathrm{Pl}$ and $\mathrm{BoP}$ were recorded in four sites per tooth.

\section{Gingival Crevicular Fluid Collection \\ GCF was collected using filter strips for 30 s and the GCF volume absorbed by each strip was determined using the Periotron $8000^{\circledR}$ (ProFlow Inc., North Haven, CT, USA). Before}


sampling, supragingival plaque was carefully removed and the teeth were air-dried and isolated with cotton rolls. Strips with blood contamination were discarded. GCF was collected from five deep sites with $P D \geq 5 \mathrm{~mm}$ and CAL $\geq 3 \mathrm{~mm}$ and from five shallow sites with $\mathrm{PD} \leq 3 \mathrm{~mm}$ and $\mathrm{CAL}$ $\leq 1 \mathrm{~mm}$. Samples from the same category (deep or shallow) in each patient were pooled together in an Eppendorf tube containing $300 \mu \mathrm{L}$ of phosphate-buffered saline.

After elution for $30 \mathrm{~min}$ at room temperature, the samples were centrifuged at $1000 \mathrm{x} g$ for $5 \mathrm{~min}$ to remove cells and the supernatant was collected and immediately frozen at $-70{ }^{\circ} \mathrm{C}$ until analysis. The value observed in the Periotron $8000^{\circledR}$ was converted into microliters using a standard curve obtained after calibration of the instrument and presented as the volume of GCF per category of site.

\section{Detection of Cell-Derived Microparticles}

Cell-derived MPs were detected by flow cytometry based on their size and the expression of membranespecific markers. Thirty microliters of GCF was incubated with fluorochrome-labeled antibodies for $30 \mathrm{~min}$ at 40 $\mathrm{C}$ in the dark. Two different antibodies were used: antiCD66b-PerCP-Cy5.5 (clone G10F5) to detect neutrophilderived MPs and anti-CD41b-FITC (clone HIP2) to detect platelet-derived MPs. All antibodies were purchased from BD Biosciences (BD Biosciences, USA). After incubation, samples were diluted in $250 \mu \mathrm{L}$ of phosphate-buffered saline. We used Fluorescence Minus One and unstained controls to evaluate non-specific fluorescence, instead of isotype controls, when defining positive events.

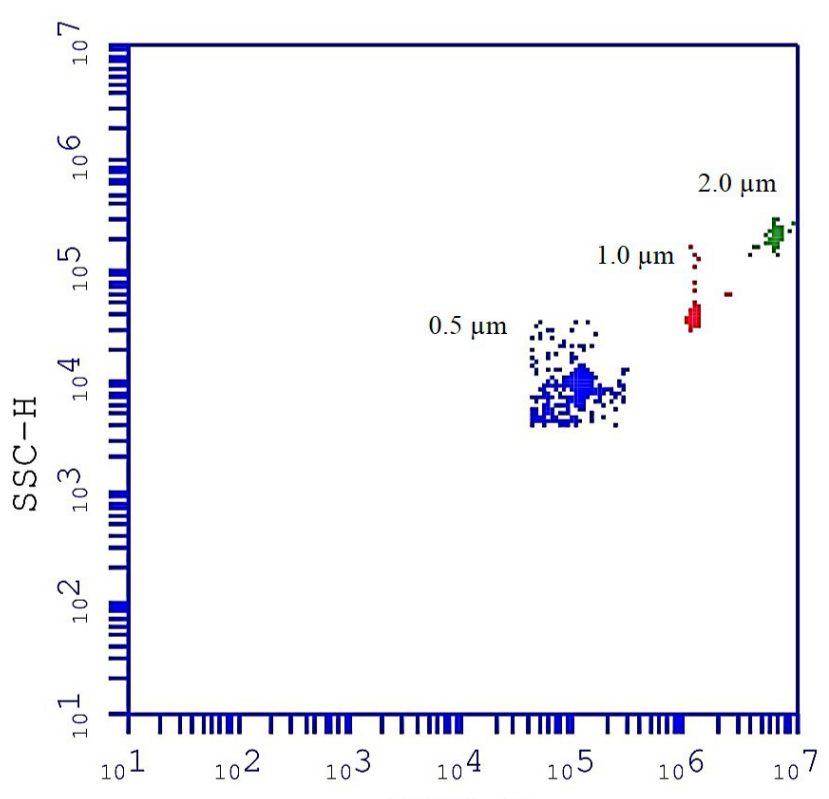

A MP gate was established using size-calibrated fluorescent beads $(0.5 \mu \mathrm{m}, 1.0 \mu \mathrm{m}$ and $2.0 \mu \mathrm{m}$; Life Technologies, Carlsbad, CA, USA). Beads were first identified based on their fluorescence and plotted on fluorescence versus side scatter dot-plot. Then, beads were gated in forward scatter versus side scatter dot-plot on logarithmic scales. Forward scatter threshold was set at 1,000. MPs were defined as events $<1 \mu \mathrm{m}$ (Fig. 1). Events in the MP gate were then plotted on 1- and 2-color fluorescence histograms. Samples were analyzed on the Accuri ${ }^{\text {TM }}$ C6 (BD Biosciences) and stopped when events reached 30,000 . The following formula was used to calculate MP counts/ $\mu \mathrm{L}$ (9):

((Number of positive events)/(Volume of sample analyzed) $x$ (Total volume of the sample)/(Amount of sample))

A cell lysis buffer (BD Biosciences) was used to lyse MPs and to evaluate the interference of immune complexes on MPs labelling. Lysis buffer was incubated with the samples just before the analysis by flow cytometry.

\section{Statistical Analysis}

Statistical analysis was performed using the Statistical Package for the Social Sciences, version 20 (IBM, USA). As MP data were non-parametric, they are presented as median and interquartile range. Comparisons between deep and shallow sites were performed with Wilcoxon test. Correlation between MP data and periodontal parameters was analyzed with Spearman's rank correlation coefficient.

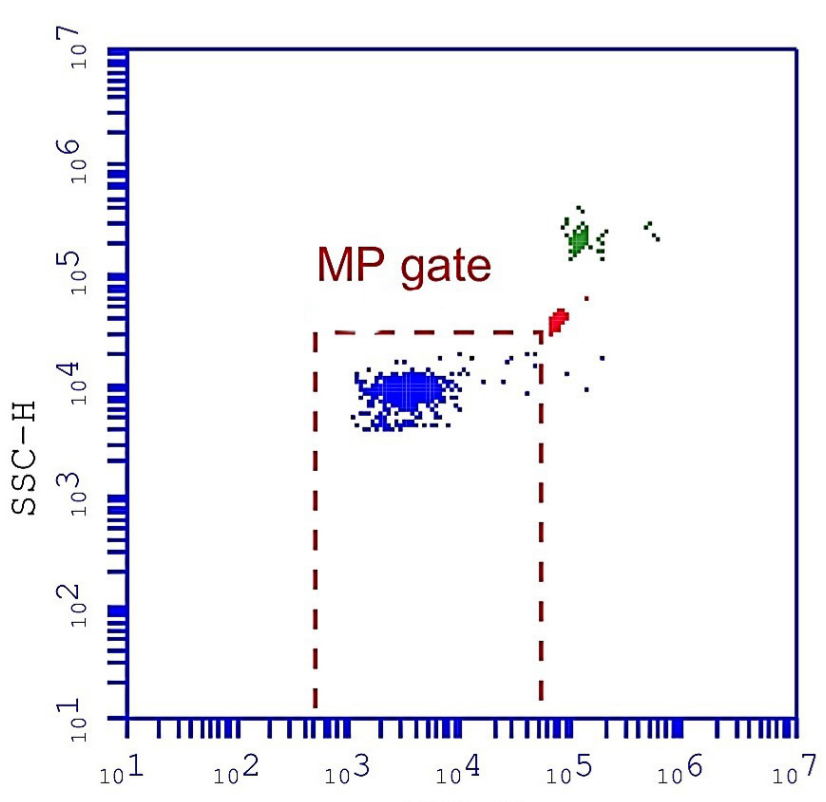

Figure 1. Determination of microparticles (MPs) gate using calibrated fluorescent beads with different sizes (0.5 $\mu \mathrm{m}, 1.0 \mu \mathrm{m}$ and $2.0 \mu \mathrm{m})$. A) Detection of calibrated beads based on their fluorescence. B) Establishing the MPs gate as events $<1 \mu \mathrm{m}$. 
Statistical significance was defined as $p<0.05$

\section{Results}

This study evaluated 12 patients, 7 female and 5 male, with mean age of $56.2 \pm 7.2$ years. Mean level of $\mathrm{HbA} 1 \mathrm{c}$ was $8.0 \pm 2.3 \%$. Mean number of teeth, $\mathrm{PI}$ and BoP were, respectively $22.0 \pm 4.1,57.6 \pm 34.3 \%$ and $50.5 \pm 33.5 \%$. Mean PD and CAL were $3.3 \pm 0.9 \mathrm{~mm}$ and $4.4 \pm 1.2 \mathrm{~mm}$, respectively. Median amount of GCF was, respectively, 3.45 (0.88 - 6.72) $\mu \mathrm{L}$ and $0.75(0.13-1.00) \mu \mathrm{L}$ in deep and shallow sites.

A representative dot-plot of MPs expressing CD66b and CD41b in gingival crevicular fluid is depicted in Figure 2. Median levels of CD66b+MPs and CD41b+MPs were, respectively, 3,677.0 $(2,553.2-9,059.8) \mathrm{MP} / \mu \mathrm{L}$ and 520.7 (432.9 - 766.1) $\mathrm{MP} / \mu \mathrm{L}$ in deep sites. In shallow sites, the corresponding values were $2,644.9(1,451.5-3,858.9)$ $\mathrm{MP} / \mu \mathrm{L}$ and $371.2(287.2$ - 692.7) MP/ $\mathrm{LL}$. There was no significant difference between them. After the incubation with the lysis buffer, the numbers of positive CD66b MPs decreased $43.5 \%$ and the numbers of positive CD41b MPs decreased $36.4 \%$.

\section{Discussion}

The present study succeeds in the attempt of detecting both neutrophil and platelet derived microparticles in gingival crevicular fluid collected from patients having both severe periodontitis and type 2 diabetes. To the best of our knowledge, our study is the first report about MPs presence in periodontal disease. The impact of the presence of neutrophil derived MPs in the periodontal

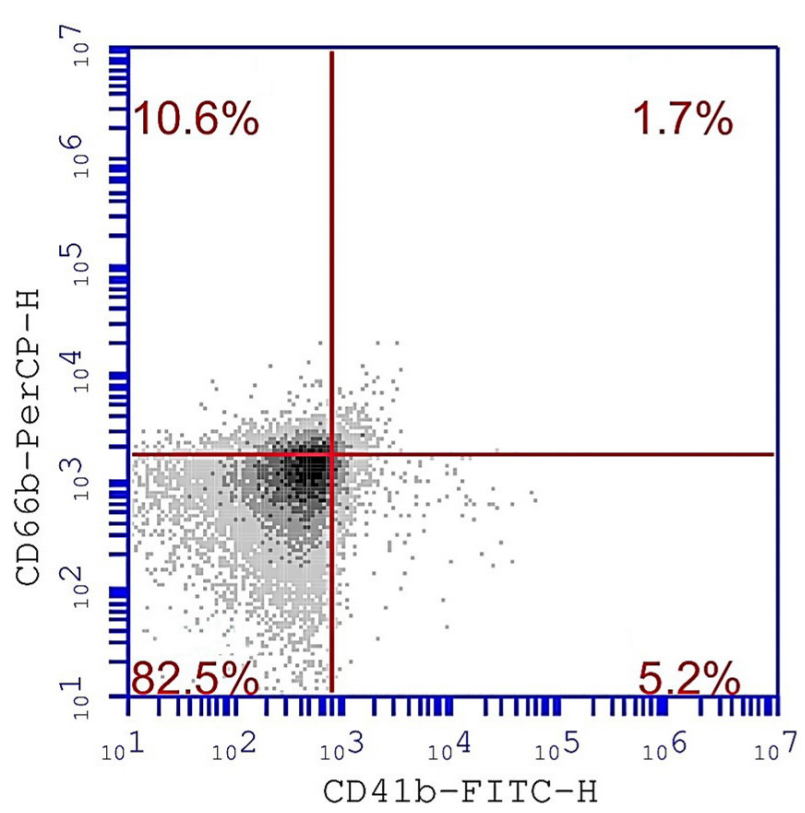

Figure 2. Representative dot-plot illustrating the microparticles expressing CD66b and CD41b in gingival crevicular fluid. lesion is unknown. Recently, Johnson et al. (10) reported that neutrophil derived MPs enhance immune dysfunction in sepsis by blunting the function of neutrophils and macrophages. Moreover, Butin-Israeli et al. (11) showed that deposition of neutrophil MPs onto inflamed epithelium might be a new mechanism to disrupt epithelial intercellular adhesions and promote transepithelial migration. Taken together, one might speculate that blunting neutrophils function and increasing disruption of the epithelial might also be present in the periodontal inflammation and, therefore, be relevant for disease progression by impairing infection control during biofilm formation around teeth.

We also consistently showed the presence of platelet derived MPs in GCF from periodontal lesion. These MPs have a significant role in immune responses, inflammation, angiogenesis, tissue regeneration and cancer metastasis mainly by communication and signal delivery (12) and which might be involved in the signaling to the periodontal collagen and bone breakdown.

In conclusion, this study reported the presence of neutrophil and platelet derived microparticles in gingival crevicular fluid from individuals having severe periodontitis and type 2 diabetes.

\section{Acknowledgements}

To the Research Foundation of the Rio de Janeiro State (FAPERJ) and the Brazilian National Council for Scientific and Technological Development (CNPq).

\section{Resumo}

As microparticulas derivadas de células (MPs) têm sido descritas como contribuintes vitais para o processo inflamatório. No entanto, seu papel na patogênese da doença periodontal permanece obscuro. Por isso, nosso objetivo foi detectar a presença de micropartículas derivadas de neutrófilos (CD66b +) e plaquetas (CD41b + ) no fluido gengival de indivíduos com periodontite e diabetes tipo 2 . Doze pacientes $(56,2 \pm 7,2$ anos) com periodontite crônica severa e diabetes tipo 2 foram incluídos no estudo. Foram coletados dados clínicos e metabólicos. 0 fluido gengival foi coletado usando tiras de filtro de papel em sítios rasos e profundos. As MPs foram detectadas por citometria de fluxo de acordo com o seu tamanho $(<1 \mu \mathrm{m})$ e pela expressão de marcadores de superfície (CD66b para MPs derivadas de neutrófilos e CD41b para MPs derivadas de plaquetas). Todas as amostras foram positivas para os anticorpos. Os niveis médios de CD66b + MPs e CD41b + MPs foram, respectivamente, 3.677.0 (2,553.2

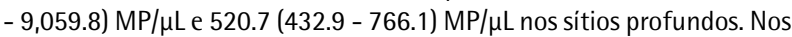
sitios rasos, os valores correspondentes foram 2,644.9 $(1,451.5$ - 3,858.9) $\mathrm{MP} / \mu \mathrm{L}$ e 371.2 (287.2 - 692.7) MP/ $\mu \mathrm{L}$. Não houve diferença significativa entre os sitios rasos e profundos ( $p>0.05$ ). Concluindo, o presente estudo reportou a presença de micropartículas derivadas de neutrófilos e plaquetas no fluido gengival de pacientes com periodontite e com diabetes tipo 2 .

\section{References}

1. Buzas El, Gyorgy B, Nagy G, Falus A, Gay S. Emerging role of extracellular vesicles in inflammatory diseases. Nat Rev Rheumatol 2014;10:356-364.

2. Knijff-Dutmer EA, Koerts J, Nieuwland R, Kalsbeek-Batenburg EM, van de Laar MA. Elevated levels of platelet microparticles are associated 
with disease activity in rheumatoid arthritis. Arthritis Rheum 2002;46:1498-1503.

3. Ren JG, Man QW, Zhang W, et al. Elevated level of circulating plateletderived microparticles in oral cancer. J Dent Res 2016;95:87-93.

4. Sabatier F, Darmon P, Hugel B, et al. Type 1 and type 2 diabetic patients display different patterns of cellular microparticles. Diabetes 2002;51:2840-2845.

5. Novelli F, Neri T, Tavanti L, et al. Procoagulant, tissue factor-bearing microparticles in bronchoalveolar lavage of interstitial lung disease patients: an observational study. PloS one 2014;9:e95013.

6. Viñuela-Berni V, Doniz-Padilla L, Figueroa-Vega N, Portillo-Salazar $H$, Abud-Mendoza C, Baranda $L$, et al.. Proportions of several types of plasma and urine microparticles are increased in patients with rheumatoid arthritis with active disease. Clin Exp Immunol 2015;180:442-451.

7. Tsimerman G, Roguin A, Bachar A, Melamed E, Brenner B, Aharon A. Involvement of microparticles in diabetic vascular complications. Thromb Haemost 2011;106:310-321.

8. Page RC, Eke PI. Case definitions for use in population-based surveillance of periodontitis. J Periodontol 2007;78:1387-1399.
9. van lerssel SH, Van Craenenbroeck EM, Conraads VM, Van Tendeloo VF, Vrints CJ, Jorens PG, et al.. Flow cytometric detection of endothelial microparticles (EMP): effects of centrifugation and storage alter with the phenotype studied. Thromb Res 2010;125:332-339.

10. Johnson BL 3rd, Midura EF, Prakash PS, Rice TC, Kunz N, Kalies K, et al. Neutrophil derived microparticles increase mortality and the counterinflammatory response in a murine model of sepsis. Biochim Biophys Acta 2017;1863:2554-2563.

11. Butin-Israeli V, Houser MC, Feng M, Thorp EB, Nusrat A, Parkos CA, et al.. Deposition of microparticles by neutrophils onto inflamed epithelium: a new mechanism to disrupt epithelial intercellular adhesions and promote transepithelial migration. FASEB J 2016;30:4007-4020.

12. Varon D, Shai E. Platelets and their microparticles as key players in pathophysiological responses. J Thromb Haemost 2015;13 Suppl 1:S4046.

Received February 23, 2017 Accepted July 26, 2017 